Pak. j. sci. ind. res. Ser. B: biol. sci. 2014 57(3) 129-135

\title{
Nutritional Evaluation of Nigerian Dried Okra (Abelmoschus esculentus) Seeds
}

\author{
Henry Niyi Ogungbenle* and Esther Funmilayo Arekemase \\ Department of Chemistry, Ekiti State University, P.M.B. 5363, Ado-Ekiti, Nigeria
}

(received January 16, 2013; revised October 9, 2013; accepted October 10, 2013)

\begin{abstract}
The proximate, functional properties, in-vitro multi enzyme protein digestibility and amino acid compositions of Nigerian dried okra (Abelmoschus esculentus) seeds were evaluated. The ash, moisture, fat, crude fibre, crude protein and carbohydrate of the okra seeds were: $4.8 \%, 13.5 \%, 39.9 \%, 8.82 \%, 26.4 \%$ and $6.62 \%$, respectively. The water and oil absorption capacities were: $220 \%$ and $200 \%$ which makes okra seeds exhibit a high water retention capacity. The least gelation concentration was $8 \%$ while, emulsion capacity was $45.5 \%$ and foaming capacity and stability were: $12 \%$ and $2 \%$, respectively. The in vitro protein digestibility was $69.3 \%$. Glutamic acid was the most concentrated amino acid $(121.1 \mathrm{mg} / \mathrm{g}$ crude protein) while, cystine $(10.0 \mathrm{mg} / \mathrm{g}$ crude protein) was the least concentrated amino acid. The total amino acid was $706 \mathrm{mg} / \mathrm{g}$ crude protein.
\end{abstract}

Keywords: functional properties, digestibility, amino acid, okra seeds

\section{Introduction}

Okra (Abelmoschus esculentus) is a popular and important vegetable in tropical and warm temperate regions of the world. It belongs to the mallow family and contains a sticky mucilage that helps to improve digestion and may be used in the treatment of gastritis, gastric ulcer and liver/gal bladder cleansing (Daniluk, 2012). Okra is originated from tropical Africa and Asia (Kochhar, 1986) and it is widely cultivated and commonly consumed non-leafy vegetable which provides essential minerals, $\beta$ carotene and vitamin $\mathrm{B}_{6}$ required for the body growth, vision and maintenance of skin (Daniluk, 2012; Choudhury, 1977). The fruit when freshly harvested and washed can be eaten raw without cooking especially during traditional naming ceremony among 'yorubas' in south west of Nigeria. The west African okra is an annual or biannual crop which does not grow much taller than about $2 \mathrm{~m}$ with few tender branches. The A. esculentus is highly polymorphic species and the stem is woody and hairy when mature (Kochhar, 1986). The leaves alternate up to $30 \mathrm{~cm}$ in length, 3-5 lobes. The fruit is greenish in colour, hairy, somewhat spiny, round and short pointed pyramidal shape. It is about $10-25 \mathrm{~cm}$ in length and $2-3 \mathrm{~cm}$ in diameter. The number of seeds in a pod vary from about 20 to 150 , depending on the fruit size. The seeds are 4-5 $\mathrm{mm}$ in diameter, dark green to grey-black, rounded with conspicuous caruncle (Irvine,1969). Okra thrives in a well drained sandy loam with a pH of 6-6.8 and is moderately tolerant

*Author for correspondence; E-mail: httphenryo@yahoo.com to salinity and usually adapts to high temperatures, but heat coupled with low humidity slows down its growth considerably (Irvine, 1969). Okra seed is a good source for extracting greenish yellow oil useful for both domestic and industrial purposes. It also have so many medicinal uses apart from its nutritional values. These include: elimination of toxins and excess cholesterol from the body, reduction of colorectal cancer (Daniluk, 2012). Bile largely soaks up acids and toxins from the body due to fairly high fibre content during the process of digestion, the soluble pectin-based mucilaginous fibre in okra binds with this toxic bile and allows it to be eliminated quickly. If these toxic materials stay in the bowel too long may be reabsorbed causing inflammation thereby leading to bowel disease. This same process eliminates excess cholesterol from the body thereby lowering serum cholesterol levels and reducing the risk of heart disease. It helps to maintain body immune system functioning and blood sugar regulation. The significance of the present study is to determine the proximate, functional properties, in vitro protein digestibility and amino acids of okra seeds. The data generated would provide new nutritional literature.

\section{Materials and Methods}

The dried okra pod samples were purchased from Oja Oba Market in Ado-Ekiti, Ekiti State, Nigeria. Seeds were separated from the pods then sun dried for 5 days and blended into flour. The flour was packaged into air tight polyethylene bag for further analyses. 
The proximate analysis of the sample for total ash, moisture, crude fibre and ether extract were carried out using the method described by AOAC (2005). The nitrogen content was determined by micro Kjedahl method described by Pearson (1976) and nitrogen content was converted to protein by multiplying by a factor 6.25 . The carbohydrate content was determined by method of difference:

$\%$ carbohydrate $=[100-(\%$ moisture $+\%$ ash $+\%$ crude fibre $+\%$ crude fat $+\%$ crude protein). All determinations were done in triplicates.

The method of Sathe et al. (1982) was used to determine gelation property with slight modification. The water and oil absorption capacities of the sample were determined as described by Beuchat (1977). The emulsion capacity and stability were determined by the method of Inklaar and Fortuin (1969) while, foaming capacity and stability were determined by method of Coffmann and Garcia (1977). The protein solubility as a function of $\mathrm{pH}$ was determined by method described by AOAC (2005). The graph of protein solubility (\%) against $\mathrm{pH}$ was plotted using the data obtained. The multi enzyme digestibility was determined using the method of Hsu et al. (1977). Aqueous suspension $50 \mathrm{~mL}$ of the sample (6.25 $\mathrm{mg}$ sample per $\mathrm{mL}$ ) in distilled water was adjusted to $\mathrm{pH} 8.0$ with $0.1 \mathrm{M} \mathrm{HCl}$ and/or $\mathrm{NaOH}$, while stirring in a $37^{\circ} \mathrm{C}$ water bath. The multi enzyme solution $(1.6 \mathrm{mg}$ trypsin, $3.1 \mathrm{mg}$ chymotrypsin and $1.3 \mathrm{mg}$ peptidase per $\mathrm{mL}$ ) was maintained in an ice bath and adjusted to $\mathrm{pH} 8.0$ with $0.1 \mathrm{M} \mathrm{HCl} /$ or $\mathrm{NaOH} .5 \mathrm{~mL}$ of the protein multi enzyme solution was then added to the protein suspension which was being stirred at $37^{\circ} \mathrm{C}$. A rapid decline in $\mathrm{pH}$ occurred immediately. The $\mathrm{pH}$ drop was recorded automatically over a $10 \mathrm{~min}$ period and $15 \mathrm{~min}$ using a $\mathrm{pH}$ meter. The multi enzyme digestibility was calculated using the regression equation of Hsu et al. (1977) as follows:

$$
\mathrm{Y}=210.46-18.10 \mathrm{x}
$$

where:

$\mathrm{Y}=$ in vitro digestibility $(\%), \mathrm{x}=\mathrm{pH}$ of the sample suspension after 10 and 15 min digestion with the multi enzyme solution.

The amino acid profile was determined using the method described by Spackman et al. (1958). The sample was dried to constant weight, defatted using Soxhlet extractor and hydrolysed in sealed glass ampoule at $105^{\circ} \mathrm{C} \pm 5^{\circ} \mathrm{C}$ for $22 \mathrm{~h}$ using $7 \mathrm{~mL}$ of $6 \mathrm{M} \mathrm{HCl}$. The hydrolysate was evaporated in a rotary evaporator and loaded into the Technicon sequential multi sample amino acid analyser (TSM, Taryton, USA).

Estimation of isoelectric point (Pi). The estimation of the isoelectric point (PI) for a mixture of amino acids was calculated using the equation below:

$$
\mathrm{IPm}=\Sigma \mathrm{IPiXi}
$$

where:

$\mathrm{IPm}=$ the isoelectric point of the $\mathrm{i}^{\text {th }}$ amino acid in the mixture and $\mathrm{Xi}=$ the mass or mole fraction of the $\mathrm{i}^{\text {th }}$ amino acid in the mixture (Olaofe and Akintayo, 2000).

Estimation of quality of dietary protein. Total amino acid scores were calculated based on the whole hen's egg amino acid profile (Paul et al., 1976), while, the essential amino acid scores were calculated using the following (FAO/WHO, 1973):

Amino acid score $=$ amount of amino acid per test protein $[\mathrm{mg} / \mathrm{g}]$ amount of amino acid per protein in reference pattern $[\mathrm{mg} / \mathrm{g}]$.

Predicted protein efficiency ratio (P-PER*) was determined using one of the equations developed by Alsmeyer et al. (1974) as follows:

$$
\text { P-PER* }=-0.468+0.454(\text { Leu })-0.105(\text { Tyr })
$$

\section{Results and Discussion}

Table 1 presents the result of the proximate analysis of okra seeds. The value of ash in okra seeds is higher than those of Moringa oleifera leaves (2.40\%), stem $(0.70 \%)$ and root $(2.05 \%)$ reported by Olaofe et al. (2013), quinoa flour (Ogungbenle, 2003), Luffa cylindrica (Olaofe and Aremu, 2008), white melon and benniseed (Ogungbenle, 2006) but lower than that of gourd seeds reported by Ogungbenle (2006). The ash content of any food substance gives an idea of the mineral present in the food. The moisture content obtained from okra seeds $(13.5 \%)$ is higher than those of bennissed, pearl millet and quinoa flour reported by Oshodi et al. (1999). Okra seeds will have a low shelf life than bennissed, pearl millet and quinoa flour due to high level of moisture and hence, inhibit the growth of microorganism. The value of crude protein in okra seeds is fairly high (26.4\%) which makes it useful as supplement for starchy foods that contains carbohydrate but low in protein. The value of crude protein in okra seeds is lower than those of L. cylindrica (32.7\%) reported by Olaofe and Aremu (2008), gourd seed (30.9\%), white melon (37.9\%) and 
Table 1. Proximate composition of dried okra seeds

\begin{tabular}{lc}
\hline \hline Parameters & $\% \mathrm{DM}$ \\
\hline Ash & 4.81 \\
Moisture & 13.5 \\
Crude protein & 39.9 \\
Crude fat & 8.82 \\
Crude fibre & 26.4 \\
Carbohydrate (by difference) & 6.62 \\
Protein digestibility & 69.3 \\
\hline \hline
\end{tabular}

$\mathrm{DM}=$ dry material.

yellow melon (28.6\%) reported by Ogungbenle (2006) but considerably higher than those of benniseed, pearl millet and quinoa, respectively, as reported by Oshodi et al. (1999). The value of crude fibre (8.82\%) of okra seed is higher than those reported for 6 varieties of African yam bean flour by Adeyeye et al. (1994), kidney bean (2.68\%) as reported by Olaofe et al. (2010), Terminalia catappa (4.94\%), reported by Nzikou et al. (2010) and 2.5\% L. cylindrica (Olaofe et al., 2008) but lower than that of quinoa flour $(9.50 \%)$ (Ogungbenle, 2003). It suggests that okra seeds would provide an added dietary fibre in the diet. The high value of fibre reported for okra seeds can improve its digestibility and absorption processes in the large intestine. Crude fat of okra seeds (6.67\%) is lower than those of L. cylindrica, $32.7 \%$ (Olaofe et al., 2008), M. bellicosus (52.73\%) and Z. variegatus (13.3\%) reported by Adeyeye (2011), benniseed, 44.30\% (Ogungbenle, 2003), T. catappa $(51.8 \%)$ reported by Nzikou et al. (2010) but comparable with that of six varieties of African yam bean flour (Adeyeye et al., 1994) and scarlet runner bean (5.3$6.9 \%$ ) reported by Aremu et al. (2005) but higher than those of quinoa flour $6.30 \%$ (Ogungbenle, 2003), kersting's groundnut (4.9\%) bambara ground-nut (6.7\%), cowpea (1.8-2.1\%), respectively, reported by Aremu et al. (2005). Okra seeds cannot replace L. cylindrica and benniseed as source of oil in food industries. Carbohydrate content in okra seeds which was determined by difference is $39.9 \%$ thus making it a fair source of carbohydrate which is essential for energy production in the human body as a result of oxidation especially, when okra seeds consumed would provide similar function. Carbohydrate content in okra seeds is slightly higher than those of Cochlospermus religiosum $(10.12 \pm 0.12 \%)$, Sesamum radiatum $(23.67 \pm 0.13 \%)$ reported by Ogungbenle et al. (2005) and L. cylindrica
(13.6\%) reported by Olaofe and Aremu (2008), 16.02\% reported for T. catappa (Nzikou et al., 2010) but considerably lower than those of quinoa flour (Ogungbenle, 2003) and pearl millet (Oshodi et al., 1999). Table 1 also shows the in vitro protein digestibility of okra seeds. The average digestibility of okra is $69.3 \%$, this value is lower than those obtained for African nutmeg (78.4\%) reported by Ogungbenle (2011), African yam bean flour (hulled seed and dehulled seeds) (Adeyeye et al., 1996) and Afzelia africana (71.5\%) reported by Ogungbenle and Omaejalile (2010) implying that they are more digestible in the body than okra seed. Digestibility of protein and bioavailability of its constituent amino acids are very important factors in determining the protein quality (FAO/WHO, 1991; Hsu et al., 1977). This is true because not all proteins are digested, absorbed and utilised to the same extent (FAO/WHO, 1991). Wallace et al. (1971) have reported that heat treatment of legume protein and protein-containing flours improves digestibility. To improve the digestibility of okra seeds it could require heat treatment. In Figure $1, \mathrm{Y}$ is in vitro digestibility (\%) and $\mathrm{X}$ is the $\mathrm{pH}$ of the sample solution after 15 min digestion with the multienzyme solution. It also shows that, as the time of heating increases, the protein digestibility of okra seeds increases, which confirms the earlier observation reported by Wallace et al. (1971). The trend of curve obtained for okra seeds agrees with that of Hsu et al. (1977).

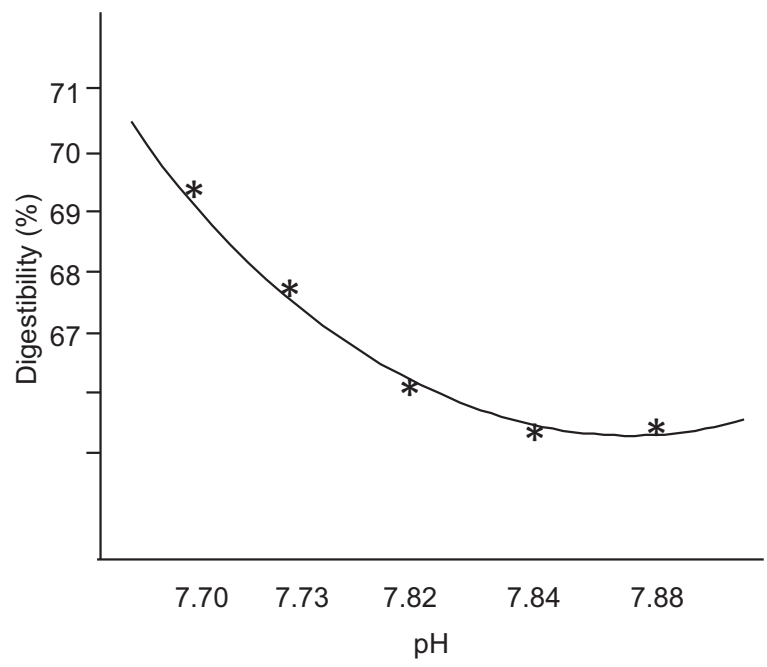

Fig. 1. The graph of protein digestibility against $\mathrm{pH}$. 
Table 2 shows the functional properties of dry okra seeds. The water absorption capacity $220 \%$ was lower than that of cowpea flour (246\%) reported by Olaofe et al. (1993) but considerably higher than those of gourd seed, white and yellow melon, benniseed, bulma cotton seed reported by Ogungbenle (2006) and quinoa flour (147.00\%) reported by Ogungbenle (2003). The high water absorptivity exhibited by the okra seeds may be useful in the formulation of some foods such as sausage, doughs, baked products etc. The sample was found to have oil absorption capacity of $200 \%$. This value is lower than that of sunflower $(270 \%)$ reported by Lin et al. (1974) but higher than most legumes such as melon seeds (122.0\%) (Olaofe et al., 1984) and pigeon pea flour (89.70\%) (Oshodi and Ekperigin, 1989). The value is also lower than those of Afzelia africana (588.49\%) reported by Ogungbenle and Omaejalile (2010) and Cucumeropsis edulis (242.1\%) reported by Ige et al. (1984). Oil absorption capacity is important since oil acts as a flavour retainer and increases the mouth feel of foods (Kinsella, 1976). Since okra seed has a higher oil absorption capacity than benniseed, pearl millet, quinoa flour (Oshodi et al., 1999), which indicates that okra seeds would be a better flavour retainer. The foaming capacity $(12 \% \mathrm{w} / \mathrm{v})$ is low thereby making okra not to be attractive for products like cakes or whipping toppings where foaming is important. Foaming capacity is lower than those of kidney bean seed (30.5\%) reported by Olaofe et al. (2010) and 68\% of pigeon pea flour (Oshodi and Ekperigin, 1989), quinoa flour (Ogungbenle, 2003), benniseed, pearl millet (Oshodi et al., 1999) but higher than $8.5 \%$ for $A$. africana (Ogungbenle and Omaejalilie, 2010) and fluted pumpkin seeds (10.8\%) reported by Fagbemi and Oshodi (1991). The least gelation concentration of okra seeds is $8 \%$ $\mathrm{w} / \mathrm{v}$. This is lower than that of A. Africana seeds $(6.00 \%$ $\mathrm{w} / \mathrm{v}$ ) reported by Ogungbenle and Omaejalile (2010). The result was better than the values reported for quinoa

Table 2. Functional properties of dried okra seeds

\begin{tabular}{ll}
\hline \hline Functional properties & $\mathbf{( \% )}$ \\
\hline Water absorption capacity & 220 \\
Oil absorption capacity & 200 \\
Foaming capacity & 12.0 \\
Foaming stability & 2.00 \\
Emulsion capacity & 45.5 \\
Emulsion stability & 67.0 \\
Least gelation concentration $(\mathrm{w} / \mathrm{v})$ & 8.00 \\
\hline \hline
\end{tabular}

flour 16\%w/v (Ogungbenle, 2003) and for fluted pumpkin seed $(36 \% \mathrm{w} / \mathrm{v})$ reported by Fagbemi and Oshodi (1991). The ability of protein to form gels and provide a structural matrix for holding water, flavour, sugar and other food ingredients is useful in food applications and in new product development, thereby providing an added dimension to protein functionality. The low value for the least gelation concentration of okra seeds indicates that it would assist in good setting of stews. Emulsion capacity (45.5\%) of okra seeds is lower than those reported for pigeon pea flour (49.4\%) reported by Oshodi and Ekperigin (1989), gourd seed, white and yellow melon, benniseed and bulma cotton seed (Ogungbenle, 2006).

The amino acid composition of okra seeds in $\mathrm{mg} / \mathrm{g}$ crude protein is shown in Table 3. Glutamic acid was the most concentrated amino acid in okra seeds with a value of $121 \mathrm{mg} / \mathrm{g}$ crude protein. Glutamic acid is essential for brain metabolism and metabolism of other amino acids. Aspartic acid was next with a value of $86.5 \mathrm{mg} / \mathrm{g}$ crude protein. Leucine has the value of $68.5 \mathrm{mg} / \mathrm{g}$ crude protein, which helps to reduce muscle protein breakdown, promotes healing of skin and broken tissues. The result followed the trend for six varieties of dehulled African yam bean flour (Adeyeye, 1997) where, glutamic and aspartic acids were the most concentrated amino acids. This observation corroborates with that reported for cooked walnut seeds (Ogungbenle, 2009). The values for glutamic acid $(121 \mathrm{mg} / \mathrm{g}$ crude protein) and aspartic acid $(86.5 \mathrm{mg} / \mathrm{g}$ crude protein) are lower than the glutamic acid ( $151.6 \mathrm{mg} / \mathrm{g}$ crude protein) and aspartic acid $(89.5 \mathrm{mg} / \mathrm{g}$ crude protein) in cooked walnut reported by Ogungbenle (2009). Cystine was the least concentrated amino acid with the value of $10.0 \mathrm{mg} / \mathrm{g}$ crude protein. This trend was also observed in white, yellow melon (Ogungbenle, 2006), where cystine was also the least concentrated amino acid. The value of cystine in okra seeds is $1.41 \%$ of the total amino acid composition. The total amino acid (TAA) of okra seeds was $705.8 \mathrm{mg} / \mathrm{g}$ crude protein. The value obtained is higher than those raw ( $439 \mathrm{mg} / \mathrm{g}$ crude protein), steeped (432 mg/g crude protein), germinated (464 mg/g crude protein) (Adeyeye, 2009) and L. cylindrical reported by Olaofe et al. (2008) but lower than that obtained in six varieties of dehulled African yam bean flour (Adeyeye, 1997). Okra seeds can be said to be considerably rich source of essential amino acids. Total essential amino acid (with histidine) had a value of $376 \mathrm{mg} / \mathrm{g}$ crude protein and $354 \mathrm{mg} / \mathrm{g}$ crude protein (without histidine) 
Table 3. Essential amino acid profile of okra seeds (mg/g crude protein)

\begin{tabular}{llll}
\hline \hline Amino acid & Value & $\begin{array}{l}\text { Suggested } \\
\text { essential } \\
\text { amino acid } \\
\text { score pattern }\end{array}$ & $\begin{array}{l}\text { Amino acid } \\
\text { scoring based } \\
\text { on whole } \\
\text { hen's egg }\end{array}$ \\
\hline *Histidine $^{\mathrm{a}}$ & 21.4 & - & 0.89 \\
*Arginine $^{\mathrm{a}}$ & 50.1 & - & 0.82 \\
+Aspartic acid $^{\mathrm{a}}$ & 86.5 & - & 0.81 \\
Valine $^{\mathrm{a}}$ & 36.1 & 0.73 & 0.48 \\
Methionine $^{\mathrm{a}}$ & 10.4 & - & 0.34 \\
Isoleucine $^{\mathrm{a}}$ & 25.7 & 0.64 & 0.46 \\
Leucine $^{\mathrm{a}}$ & 68.5 & 0.93 & 0.83 \\
Phenylalanine $^{\mathrm{a}}$ & 42.0 & - & 0.84 \\
Met + Cys $_{\text {Phe }+ \text { Tyr }}$ & - & 0.58 & - \\
TEAA $_{\text {With histidine }}$ & - & 1.22 & - \\
Without histidine & 376 & - & - \\
\% TEAA & 354 & - & - \\
With histidine & 53.2 & - & - \\
Without histidine & 50.2 & - & - \\
Pi (calculated) & 3.98 & - & - \\
P-PER* & 2.31 & - & - \\
\hline \hline
\end{tabular}

$\overline{\text { TEAA }=\text { total essential amino acids; }{ }^{\mathrm{a}}=\text { essential amino acid; }}$ $*$ = basic amino acids; ${ }^{+}=$acidic amino acids.

with percentage TEAA value of 53.2 and $50.2 \%$, respectively, making it to form the bulk of amino acid in the okra seed (\%TEAA $>\%$ TNEAA). The sample is therefore, rich in essential amino acids. TNEAA obtained in okra seeds is considerably lower than that obtained for dehulled African yam bean flour 327.2-453.8 mg/g crude protein (Adeyeye, 1997) and $409.9 \mathrm{mg} / \mathrm{g}$ crude protein for A. africana (Ogungbenle and Omaejalile, 2010). Total essential amino acids with and without histidine is lower than the value $110-603 \mathrm{mg} / \mathrm{g}$ crude protein obtained for African yam bean flour (Oshodi et al., 1995) but higher than the values 357.3 and 337.3 $\mathrm{mg} / \mathrm{g}$ crude protein for periwinkle meat (Ogungbenle and Omowole, 2012) and African nutmeg (313.9 and $292.0 \mathrm{mg} / \mathrm{g}$ cude protein) reported by Ogungbenle and Adu (2012). The iso-electric point ( $\mathrm{P}_{\mathrm{I}}$ calculated) for the sample was 3.98. The value obtained is comparable with that of some selected oil seeds 2.8-6.3 (Olaofe and Akintayo, 2000). The value of $\mathrm{P}_{\mathrm{i}}$ is useful in predicting when their will be a quick precipitation of protein isolate from biological samples (Olaofe and Akintayo, 2000). The predicted protein efficiency ratio (P-PER*) of okra seeds was 2.31 while, experimentally determined PER usually ranged from 0.00 for a very poor protein to a maximum possible of just over 4 (Muller and Tobin, 1980). PER obtained was higher than that of $L$. cylindrica (Olaofe and Aremu, 2008) meaning that okra seeds will be more utilised in the body due to increased digestibility than L. cylindrica. Table 3 shows the amino acid scoring pattern based on the essential amino acids. Leu + Cys was observed to be the limiting amino acid with a value of 0.58 . Therefore, in order to fulfill the daily needs for the essential amino acids (EAA) in okra seeds, 100/58 or 1.72 times as much of okra seeds would have to be consumed if it is to be the sole protein in the diet.

Table 4 also indicates the non-essential amino acid scores of okra seeds based on whole hen's egg amino acid profile. Methionine (0.34) is the limiting amino acid in the sample. The factor will then be 100/34 or 2.94 times protein of okra seeds that would be taken where it would be needed as the sole protein source. This followed the trend observed in raw, steeped and fermented millet reported by Adeyeye (2009). The study is limited to the assessment of the nutritional qualities of the whole fruit and future studies on fatty acids, lipid analysis, physico chemical properties of the oil, sugar level and mineral analysis are identified.

Table 4. Non-essential amino acid profile of okra seeds (mg/g crude protein)

\begin{tabular}{llll}
\hline \hline Amino acid & Value & $\begin{array}{l}\text { Suggested } \\
\text { essential } \\
\text { amino acid }\end{array}$ & $\begin{array}{l}\text { Amino acid } \\
\text { scoring based } \\
\text { on whole } \\
\text { hen's egg }\end{array}$ \\
\hline *Lysine & 34.8 & 0.63 & 0.56 \\
Threonine & 31.5 & - & 0.62 \\
Serine & 27.9 & - & 0.35 \\
${ }^{+}$Glutamic acid & 121 & - & 1.07 \\
Proline & 31.5 & - & 0.83 \\
Glycine & 41.1 & - & 1.37 \\
Alanine & 36.5 & - & 0.67 \\
Cystine & 10.0 & - & 0.56 \\
Tyrosine & 31.7 & - & 0.79 \\
\% TNEAA & 46.9 & - & - \\
\hline
\end{tabular}

TNEAA $=$ total non essential amino acid; $*=$ basic amino acids; ${ }^{+}=$acidic amino acids.

\section{Conclusion}

Okra seed is rich in some essential amino acids, but its high level of moisture implies low shelf life of the fresh seeds. The fairly high fibre content may aid quick 
digestion process in the stomach. It is also a rich source of carbohydrate and protein which is essential for both human and livestock development. The high water and oil absorption capacities exhibited by okra seeds can be an added advantage in the formulation of foods and also as a flavour retainer. The use of okra seeds in food processing should be encouraged because of its high nutritional potentials.

\section{References}

Adeyeye, E.I. 2011. Fatty acid composition of Zonocerus variegatus, Microtermes bellicus and Anacadium occidental kernel. International Journal of Pharma and Bio Sciences, 2: 135-144.

Adeyeye, E.I. 2009. Intercorrelation of amino acid quality between raw,steeped and germinated millet grains. Pakistan Journal of Scientific and Industrial Research, 52: 122-129.

Adeyeye, E.I. 1997. Amino acid composition of six varieties of dehulled African yam bean flour. International Journal of Food Sciences and Nutrition, 48: 345-351.

Adeyeye, E.I., Oshodi, A.A., Ipinmoroti, K.O. 1994. Functional properties of some varieties of African yam bean (Sphenostylis sternoecarpa) flour II. International Journal of Food Sciences and Nutrition, 45: 115-126.

Alsmeyer, R.H., Cunningham, A.E., Hapich, M.L. 1974. Equations to predict PEF from amino acid analysis. Food Technology, 28: 34-38.

AOAC, 2005. Official Methods of Analysis, $15^{\text {th }}$ edition, Association of Official Analytical Chemist, Washington, DC., USA.

Aremu, M.O., Olaofe, O., Akintayo, E.T. 2005. Nutritional qualities assessment of the presence of hull in some Nigerian underutilized legume seeds. Bulletin of Pure and Applied Sciences, 24: 47-52.

Beuchat, L.R. 1977. Functional and electrophoretic characteristics of succinylated peanut flour. Journal of Agricultural and Food Chemistry, 25: 258-261.

Choudhury, B. 1977. Vegetables: India, the Land and the People, 214 pp., $5^{\text {th }}$ edition, National Book Trust, New Delhi, India.

Coffman, C.W., Garcia, V.V. 1977. Functional properties and amino acid content of a protein isolated from mung bean flour. International Journal of Food Science and Technology, 12: 473-484.

Daniluk, J. 2012. Health benefits of okra and a curry recipe to heal inflammation. http://www.chatelaine. com/health-benefits-of-okra.
Fagbemi, T.N., Oshodi, A. 1991. Chemical composition and functional properties of full fat fluted pumpkin seed flour. Nigerian Food Journal, 9: 26-32.

FAO/WHO, 1991. Protein Quality Evaluation: Report of the Joint FAO/WHO Expert Consultation, FAO Food and Nutrition Paper 51, held in Bethesda MD., USA, December 1989, FAO, Rome, Italy.

FAO/WHO, 1973. Energy and Protein Requirements: Report of a joint FAO/WHO Adhoc Expert Committee. FAO Nutrition Meeting Report Serial No.52 and World Health Organisation Technical Report Series No. 522, WHO, Geneva, Switzerland.

Hsu, H.W., Vavak, D.L., Satterlee, L.D., Miller, G.A. 1977. A multienzyme technique for estimating protein digestibility. Journal of Food Science, 42: 1269-1273.

Ige, M.M., Ogunsua, A.O., Oke, O.L. 1984. Functional properties of the proteins of some Nigerian oil seeds: conophor seeds and the three varieties of melon seeds. Journal of Agricultural and Food Chemistry, 32: 822-825.

Inklaar, P.A., Fortuin, J. 1969. Determining the emulsifying and emulsion-stabilizing capacity of protein meat additives. Food Technology, 23: 103-107.

Irvine, F.R. 1969. West African Crops, 272 pp., $3^{\text {rd }}$ edition, Oxford University Press, London, UK.

Kinsella, J.E. 1976. Functional properties of protein foods: a survey. CRC Critical Review in Food Science and Nutrition, 7: 219-280.

Kochhar, S. 1986. Tropical Crops. A Textbook of Economic Botany. Macmillan Publishers Limited, London, UK.

Lin, M.J.Y., Humbert, E.S., Sosulski, F.W. 1974. Certain functional properties of sunflower meal products. Journal of Food Science, 39: 368-370.

Muller, H.G., Tobin, G. 1980. Nutrition and Food Processing, 320 pp., Croom Helm, London, UK.

Nzikou, J.M., Mvoula-Tsieri, M., Pambou-Tobi, N.P.G., Ndangui, C.B., Kimbonguila, A., Silou, Th., Linder, M., Scher, J., Desobry, S. 2010. Proximate composition and physicochemical characteristics of seed and oil from Terminalia catappa $\mathrm{L}$. and the kinetics of degradation of the oil during heating. Australian Journal of Basic and Applied Sciences, 4: 2039-2047.

Olaofe, O., Adeyeye, E.I., Ojugbo, S. 2013. Comparative study of proximate amino acids and fatty acids of Moringa oleifera tree. Elixir Applied Chemistry, 54: 12543-12554.

Olaofe, O., Famurewa, J.A., Ekuagbere, A.O. 2010. Chemical and functional properties of kidney bean 
seed flour. Inernational Journal of Chemical Sciences, 3: 51-69.

Olaofe, O., Aremu, M.O. 2008. Chemical evaluation of the nutritive value of smooth Luffa cylindrica seed's kernel. Electronic Journal of Food Chemistry, 7: 3444-3452.

Olaofe, O., Akintayo, E.T. 2000. Prediction of isoelectric points of legume and oil seed proteins from their amino acid compositions. The Journal of Technoscience, 4: 49-53.

Olaofe, O., Adeyemi, F.O., Adediran, G.O. 1994. Amino acid and mineral compositions and functional properties of some oilseeds. Journal of Agricultural and Food Chemistry, 42: 878-881.

Olaofe, O., Umar, Y.O., Adediran, G. 1993. The effect of nematicides on the nutritive value and functional properties of cowpea seeds. Food Chemistry, 46: 337-341.

Ogungbenle, H.N., Adu, T. 2012. Proximate composition and functional properties of dehulled African nutmeg. Pakistan Journal of Scientific and Industrial Research, 55: 80-85.

Ogungbenle, H.N., Omowole, B.M. 2012. Chemical, functional and amino acids composition of periwinkle meat. International Journal of Pharmaceutical Science Review and Research, 13: 128-132.

Ogungbenle, H.N. 2011. Chemical, in-vitro digestibility and fatty acids composition of African nutmeg. Annals of Science and Biotechnology, 2: 46-51.

Ogungbenle, H.N., Omaejalile, M. 2010. Functional properties and anti-nutritional properties, in-vitro protein digestibility and amino acid composition of dehulled A. Africana seeds. Pakistan Journal of Scientific and Industrial Research, 53: 265-270.

Ogungbenle, H.N. 2009. Chemical and amino acid composition of cooked walnut flour. Pakistan Journal of Scientific and Industrial Research, 52: 130-133.

Ogungbenle, H.N. 2006. Chemical composition, functional properties and amino acid composition of some edible seeds. La Rivista Italia Sostasse
Grasse, 83: 71-79.

Ogungbenle, H.N., Oshodi, A., Oladimeji, M. 2005. Chemical, energy evaluation of some underutilised legume flours. La Rivista Italia Sostasse Grasse, 82: 204-208.

Ogungbenle, H.N. 2003. Nutritional evaluation and functional properties of quinoa (Chenopodium quinoa) flour. International Journal of Food Science and Nutrition, 54: 153-158.

Oshodi, A., Ogungbenle, H.N., Oladimeji, M. 1999. Chemical composition, functional properties and nutritionally valuable minerals of benniseed, pearl millet, quinoa seed flour. International Journal of Food Science and Nutrition, 50: 325-331.

Oshodi, A., Ipinmoroti, K., Adeyeye, E.I., Hall, G.M. 1995. Amino and fatty acid composition of African yam bean (Sphenostylis stenocarpa) flour. Food Chemistry, 53: 1-6.

Oshodi, A.E., Ekperigin, M.M. 1989. Functional properties of pigeon pea (Cajanus cajan) flour. Food Chemistry, 34: 187-191.

Paul, A., Southgate, D., Russel, R. 1976. Mc Cance and Widdowson's The composition of Foods, $4^{\text {th }}$ edition, The Royal Society of Chemistry, HMSO, London, UK.

Pearson, D. 1976. Chemical Analysis of Foods, $7^{\text {th }}$ edition, Churchill Livingstone, London, UK.

Sathe, S.K., Deshpande, S., Salunkhe, D.K. 1982. Functional properties of lupin seed proteins. Journal of Food Science, 47: 491-497.

Spackman, D.H., Stein, W.H., Moore, S. 1958. Automatic recording apparatus for the use in the chromatography of amino acids. Analytical Chemistry, 30: 1190-1206.

Wallace, G.M., Bannatyne, W.R., Khaleque, A. 1971. Studies on the processing and properties of soy milk. Effect of processing conditions on the trypsin inhibitor activity and the digestibility in-vitro of proteins in various soy milk preparations. Journal of The Science of Food and Agriculture, 22: 526531 . 